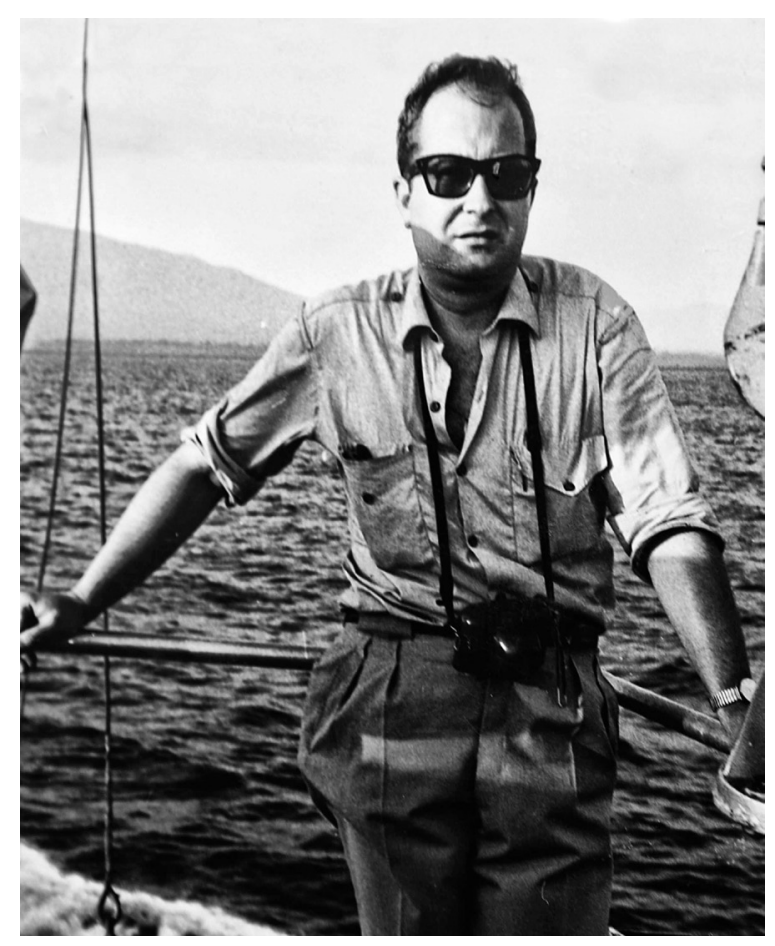

\title{
Miquel Massutí Oliver (1930-2012)
}

The Institute for Fisheries Research (IIP) of the Spanish National Research Council (CSIC) was set up in 1951 but its origin goes back to the course "Introduction to Fisheries Research" that was taught in 1949. This course was organized by the of Marine Biology Section of the CSIC's Institute of Applied Biology, directed by the zoology professor of the University of Barcelona, Francisco Garcia del Cid. The teachers were Buenaventura Andreu and Miquel Massutí Alzamora, helped in the practical classes by Ramon Margalef and Josep M. Camps, and the course was attended by students of Professor Garcia del Cid. One of these students was Miquel Massutí Oliver, a young man who, after graduating in natural sciences from the University of Barcelona, began his career in 1954 as a fellow of the CSIC in the IIP, first in Blanes, then in Vinaroz and finally in Cadiz.

Massutí specialized in the study of deep-sea crustaceans. In 1959 he joined the Spanish Institute of Oceanography (IEO) as an oceanographer and in 1977 was appointed head of the Fisheries Biotechnology Department. In 1986 he left the IEO to work for the Government of the Balearic Islands, where he organized and was responsible for the Fishing and Marine Aquaculture Service. In 1987 he was the first Director
General of Fisheries of the Autonomous Community of the Balearic Islands.

Massutí was born in Majorca in June 1930. The untimely death of his father, Miguel Massutí Alzamora, in 1950, when he was director of the IEO laboratory in Palma and a lecturer at the CSIC's Institute of Applied Biology, was a decisive event in Massutí's life. After working at the IIP, in 1959 he joined the IEO and was sent to the Balearic Islands laboratory in Palma. Over a period of 26 years he performed a wide range of research in the field of fishing biology and technology. He directed a variety of projects, involving in particular the exploration and evaluation of the deep fishing grounds of the Balearic Sea and the mainland coast. He also participated in and led numerous oceanographic research campaigns aboard Spanish, German, French and Japanese research and fishing vessels. These campaigns were conducted mainly in the western Mediterranean, the south-Atlantic coast of the Iberian Peninsula and the African Atlantic. In 1962 he began to represent Spain in international fisheries research forums, on the General Fisheries Council for the Mediterranean (GFCM) of the United Nations Food and Agriculture Organization (FAO) and also in parliamentary assemblies of the Council of Europe and the OECD. He was 
vice-chair of the FAO World Conference on Biology and Culture of Crustaceans held in Mexico in 1967 and vice-chair of the Technical Consultation on red coral in the Mediterranean held in Majorca in 1983. In the early 1970s he began to systematically study sport fishing and recreational fishing, arguing that they were important for fisheries research. Later, as Director General of Fisheries, he controlled and regulated these types of fishing.

His scientific work led to a number of publications in Spanish and international journals related to biology and fishing technology. He wrote books and articles for the general public on fishing and environmental issues and was also very active as a lecturer, seminar leader and teacher in marine and fisheries subjects. He also left a mark on many students during his time as a natural science teacher at several secondary schools in Palma. Massutí married Enriqueta Pascual and they had four children, Miquel, Immaculada, Enric and Dolors, two of whom are biologists.

Fisheries research was the focus of his work and he was always in close contact with the fishing industry. At a time when contraband was still thriving and the tourist boom had not yet started, Massutí and his cousin, Miquel Oliver Massutí, drew up the fishing charts of the Balearic Islands and the Spanish Mediterranean coast. Their work generated a line of research that continues uninterrupted today. As the fishing sector was well-funded, the fishing charts and new technology allowed trawlers to fish in deeper areas and to extend the fishing grounds. The result was the successful exploitation of fisheries of the continental slope of the Balearic Islands, and especially deep-sea prawn fishing, which is still profitable 50 years later and is a good example of what is now known as knowledge transfer to industry.

In the 1970s both Massutí and his friend Pedro Suau belonged to the small group of scientific advisers of the Standing Committee on Fisheries of the Mediterranean. This marked a return to the collaboration between the IIP and the IEO that had declined after the death of Massutî's father in 1950. Massutí was chair of the Federation of Fishermen of the Balearic Islands, which promoted the construction of El Pescador, a multipurpose fishing research vessel owned by the fishing industry. This vessel was self-funding through fishing but devoted part of its efforts to research under the direction of the IEO.

Massutí was a vocational oceanographer, a researcher, a manager, a teacher, an illustrator and a popularizer of marine biology. He loved the sea and shared the everyday concerns and problems of fisheries and fishermen, serving them in the public administration through scientific research and fisheries management.

Massutí had been my teacher and friend since I attended the Luis Vives secondary school. I remember his words upon hearing of the death of his cousin, my father, Miquel Oliver Massutí, in January 2004: "even more than pain, I felt in my whole being a sensation of unrest, of uneasiness, that was almost physical". I now share these words.

Miquel Massutí, my uncle, my friend, my teacher, died on April 10, 2012. Rest in peace.

PERE OLIVER

Spanish Institute of Oceanography (IEO) 